\title{
Development of a method for simultaneous analysis of caffeine and taurine in energy drinks by micellar electrokinetic chromatography with diode-array detector
}

\author{
Alane Cangani ALVES ${ }^{1 *}$ (D), Adriana Dillenburg MEINHART ${ }^{1}$, José TEIXEIRA FILHO², Helena Teixeira GODOY ${ }^{1}$
}

\begin{abstract}
The objective of this study was to develop, optimize and validate a fast and reliable method for the simultaneous determination of caffeine and taurine contents by micellar electrokinetic chromatography with diode array detector, using direct and indirect detection concomitantly. Multivariate statistical techniques were used as a central composite design and the simultaneous optimization method of responses of Derringer and Suich were used for optimization. The method was applied in the analysis of 73 samples of energy drinks commercialized in Brazil. The optimized method employed a capillary tube with an extended bulb of $50 \mu \mathrm{m}$ i.d. x $72 \mathrm{~cm}$ total length, an electrolyte containing $16.20 \mathrm{mmol.L^{-1 }}$ of benzoic acid and $39.90 \mathrm{mmol.L} \mathrm{L}^{-1}$ of SDS, a $\mathrm{pH}$ value of 7.26, $+30 \mathrm{kV}$ voltage, direct detection of caffeine at $274 \mathrm{~nm}$ and indirect detection of taurine at $230 \mathrm{~nm}$. Validation parameters have demonstrated the reliability and applicability of this method. It was found that more than $50 \%$ of the samples were out of the legal limits determined by the Brazilian government regarding the taurine content and $68 \%$ contained caffeine below the value declared on the label. Therefore, the need for greater control concerning the composition of these drinks exists.
\end{abstract}

Keywords: multivariate optimization; added ingredients; capillary electrophoresis.

Practical Application: Development of method for simultaneous determination of caffeine and taurine content in energy drink.

\section{Introduction}

According to the Brazilian Health Regulatory Agency (ANVISA), energy drink is defined as a "liquid compound ready for consumption", and may present the following ingredients in its composition: inositol and/or glucuronolactone (maximum $20 \mathrm{mg} .100 \mathrm{~mL}^{-1}$ ), and/or taurine (maximum $400 \mathrm{mg} \cdot 100 \mathrm{~mL}^{-1}$ ), and/or caffeine (maximum $35 \mathrm{mg} .100 \mathrm{~mL}^{-1}$ ), vitamins and/or minerals (up to $100 \%$ of the Reference Daily Intake); other ingredients can be added, provided that there is no distortion of the product (Brasil, 2005).

Caffeine is considered one of the most common ingredients to any brand of energy drink (Paula Lima \& Farah, 2019; McLellan et al., 2016; Rai et al., 2016; Turak et al., 2017). In the human body, it has a stimulation effect both in the central nervous system and the cardiac activities (Paula Lima \& Farah, 2019; McLellan et al., 2016; Seifert et al., 2011). However, when ingested at doses above $400 \mathrm{mg} /$ day (considering a $70 \mathrm{~kg}$ adult) it may cause anxiety and other undesirable symptoms (McLellan et al., 2016; Reid et al., 2016; Temple, 2019; Tran et al., 2016; Turak et al., 2017). From $1.000 \mathrm{mg} / \mathrm{day}$, it presents toxicity to the organism, and it may be lethal in quantities of 5.000 to $10.000 \mathrm{mg}$ /day (Seifert et al., 2011).

Taurine is a free amino acid which plays a fundamental role in the human body by absorbing fats, protecting the heart and acting as an antioxidant (Alzawqari et al., 2016; Catharino et al., 2011; Giles et al., 2012; Goron \& Moinard, 2018; Heidari et al., 2016; Mele et al., 2019; Pansani et al., 2012; Pereira et al., 2012;
Rai et al., 2016; Wen et al., 2019). Regarding toxicity, it is generally well accepted by the body, without any adverse physiological effects. It is estimated that the world population consumes about $400 \mathrm{mg}$ per day (Sanctis et al., 2017) and there are no reports of side effects regarding the therapeutic use of doses between 1.000 and $3.000 \mathrm{mg}$ per day (Heckman et al., 2010; Jakopin, 2019).

Both caffeine and taurine content are usually determined by high-performance liquid chromatography with diode array detector (HPLC-DAD) (Bizzotto et al., 2013; Chirita Tampu et al., 2018; Paula Lima \& Farah, 2019; Rai et al., 2016) and capillary electrophoresis, mainly zone or micellar electrokinetic chromatography (MEKC) with diode array detector (DAD), is also often employed. However, taurine does not absorb light in the UV - VIS region, being detected indirectly, either by $\mathrm{DAD}$, or by laser - induced fluorescence, amperometric and conductometric detectors (Rai et al., 2016; Sawabe et al., 2008; Vochyánová et al., 2014; Zinellu et al., 2009).

The main difficulty in the development of a method for simultaneous analysis of caffeine and taurine consists of the detection mechanism to be applied. Simultaneous analysis of two compounds has been already described in studies that employed HPLC with detector by mass spectrometry and by MEKC with two connected detectors, being the DAD for caffeine and the conductometer for taurine (Vochyánová et al., 2014; Welch et al., 2015). The use of two methods makes this analysis slow and laborious, which highlights the importance of

${ }^{1}$ Departamento de Ciência de Alimentos, Faculdade de Engenharia de Alimentos, Universidade Estadual de Campinas - UNICAMP, Campinas, SP, Brasil

${ }^{2}$ Faculdade de Engenharia Agrícola, Universidade Estadual de Campinas - UNICAMP, Campinas, SP, Brasil

*Corresponding author: alanecangani@gmail.com 
the development of methods with the simple and simultaneous detection of the two compounds. The technique of capillary electrophoresis has been increasingly used due to high resolution, speed, low cost and low residual generation, which is the reason why this technique is an important tool for analyses such as caffeine and taurine.

Therefore, the objective of this study was to develop, optimize and validate a method for simultaneous determining of caffeine and taurine content, using MEKC-DAD and multivariate statistical techniques, applying the method in the analysis of 22 energy drink brands commercialized in Brazil.

\section{Materials and methods}

\subsection{Samples}

For the development and optimization of this method, a single brand of energy drinks was obtained in Campinas- SP, whose composition was considered the most complex in comparison with other brands.

For the evaluation of caffeine and taurine content, 22 brands of energy drinks were obtained in supermarkets in the city of Campinas, each one from three different batches of five brands, only two batches were acquired due to lack of availability, totaling 73 samples. The preparation of the samples consisted in degassing in ultrasound for 20 minutes and filtering in a $0.22 \mu \mathrm{m}$ Millipore filter (Millipore, USA), before injection in the capillary electrophoresis system. All determinations were made in triplicate, and each replicate represented an average of three injections.

\subsection{Reagents}

Benzoic acid was purchased from Carlo Erba (Cornaredo, Ml, Italy) and sodium dodecyl sulfate (SDS) from Riedel-de-Haën (Seelze, NI, Germany). Caffeine and taurine standards were purchased from Sigma-Aldrich (St. Louis, MO, USA). All solutions were prepared with ultrapure water (Milli-Q ${ }^{\circledR}$ system from Millipore Corporation (Jaffrey, NH, USA) and filtered in a $0.22 \mu \mathrm{m}$ cellulose membrane porosity (Millipore, Jaffrey, NH, USA). Stock solutions of caffeine and taurine, as well as the solutions in this study, were stored under refrigeration temperatures $\left(10^{\circ} \mathrm{C}\right)$.

\subsection{Equipment}

The equipment used was the Agilent G1600AX capillary electrophoresis system (Agilent Technologies, Germany), equipped with diode array detector (DAD), automatic injector and temperature control system adjusted to $25{ }^{\circ} \mathrm{C}$. A fused silica capillary with $50 \mu \mathrm{m}$ of internal diameter and $72 \mathrm{~cm}$ of effective length, with extended bulb (Agilent Technologies, Germany) was used. Detection was performed at wavelengths of 230 and $274 \mathrm{~nm}$, for taurine (indirect detection) and for caffeine (direct detection), respectively. The analysis and the treatment of the data were carried out on HP ChemStation software.

\subsection{Method optimization (design) of the experiments and data processing}

The choice of the electrolyte was based on the presence of a chromophore with absorption in the UV-VIS region, allowing indirect detection of taurine. On the other hand, it does not absorb in the UV light region (200 - 210 and $274 \mathrm{~nm}$ ), enabling the direct detection of caffeine.

Then, a univariate study of the $\mathrm{pH}$ range was conducted. The range from 4.0 to 11.0 (1.0 interval) based on the pKa of compounds was studied. For such studies, we used a capillary with extended bulb of $50 \mu \mathrm{m}$ i.d. x $72 \mathrm{~cm}$ in total length, an electrolyte containing $10 \mathrm{mmol} . \mathrm{L}^{-1}$ of benzoic acid and $50 \mathrm{mmol.L} \mathrm{L}^{-1}$ of SDS, and the $\mathrm{pH}$ adjusted according to the matrix of the design, using $\mathrm{NaOH}\left(1 \mathrm{~mol} . \mathrm{L}^{-1}\right)$ and $\mathrm{HCl}\left(0.1 \mathrm{~mol} . \mathrm{L}^{-1}\right)$ solutions. The injection was hydrodynamic at $50 \mathrm{mbar}$ for $5 \mathrm{~s}$ and $+30 \mathrm{kV}$ voltage.

From the results obtained in the univariate tests, a central composite design $2^{3}$, with central and axial points, was used to investigate the individual and interaction effects between $\mathrm{pH}$ variables, electrolyte and SDS concentrations. The central point was analyzed in triplicate, totaling 17 experiments. All experiments were conducted at random. The levels employed varied from $10(-1.68)$ to $40 \mathrm{mmol} \cdot \mathrm{L}^{-1}(+1.68)$ for electrolyte concentration; $10(-1.68)$ to 50 mmol. $\mathrm{L}^{-1}(+1.68)$ for SDS concentration; and between $5.00(-1.68)$ and $10.00(+1.68)$ for $\mathrm{pH}$. Table 1 shows the matrix of central composite design, with coded and decoded variables.

Experiments were conducted by injecting an added sample of standards, at concentrations of $0.5 \mathrm{mg} \cdot \mathrm{mL}^{-1}$ for caffeine and $5 \mathrm{mg}$. $\mathrm{mL}^{-1}$ for taurine. All conditions of the central composite design were injected at $50 \mathrm{mbar}$ of pressure for $5 \mathrm{~s}$, at a temperature of $25^{\circ} \mathrm{C}$, and indirect detection at $230 \mathrm{~nm}$ for taurine and direct detection at $274 \mathrm{~nm}$ for caffeine. Before each condition of the design, a conditioning with 5 minutes of 1 mol.L $\mathrm{L}^{-1}$ of sodium hydroxide, 5 minutes of water and 10 minutes of the electrolyte of the condition under study were performed, in order to maintain the original conditions of the capillary always the same. Each experimental condition was injected in duplicate, and between runs of the same condition, the capillary was conditioned for 2 minutes with the electrolyte.

Based on the results obtained in the tests, some responses were chosen to be optimized: (1) time difference between electroosmotic flow and caffeine (to evaluate the separation between the eak of caffeine and the peak of the system); (2) resolution between caffeine and taurine, calculated according to Equation 1; (3) symmetry of the taurine peak (due to the effects of dispersion resulting from the difference in conductivity of the electrolyte and the taurine molecule), calculated according to Equation 2; (4) height of the taurine peak (to improve the detection limit); and (5) baseline variation at $230 \mathrm{~nm}$ (very significant in indirect detections). For each response, linear and quadratic models were assessed regarding lack of fit, residual distribution and significance of regression by analysis of variance (ANOVA), at the confidence level of $95 \%$.

$\mathrm{Rs}=\frac{2\left(\mathrm{t}_{2}-\mathrm{t}_{1}\right)}{\mathrm{w}_{2}+\mathrm{w}_{1}}$ 
Table 1. Variables, levels and responses of the central composite design performed for the optimization in determining taurine and caffeine content in energy drinks.

\begin{tabular}{|c|c|c|c|c|c|c|c|c|c|c|c|}
\hline \multirow[b]{2}{*}{ Test } & \multicolumn{3}{|c|}{ Coded Variables } & \multicolumn{3}{|c|}{ Decoded Variables } & \multicolumn{5}{|c|}{ Responses } \\
\hline & A & B & $\mathrm{C}$ & $\begin{array}{c}\mathrm{A} \\
\mathrm{pH}\end{array}$ & 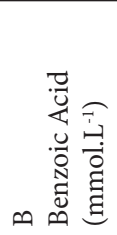 & 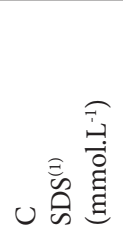 & 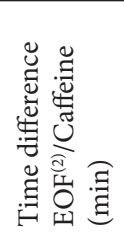 & 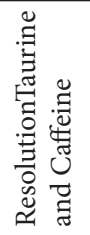 & 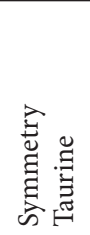 & 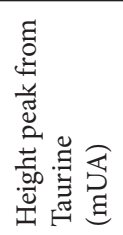 & 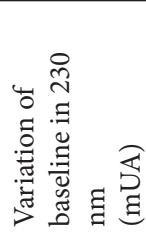 \\
\hline 3 & -1.00 & 1.00 & -1.00 & 6.00 & 33.90 & 16.10 & 0.07 & 27.5 & 7.6 & 296.2 & 156.2 \\
\hline 4 & -1.00 & 1.00 & 1.00 & 6.00 & 33.90 & 39.90 & 0.79 & 20.4 & 8.0 & 312.7 & 172.2 \\
\hline 5 & 1.00 & -1.00 & -1.00 & 9.00 & 16.10 & 16.10 & 0.20 & 12.1 & 10.3 & 514.2 & 24.0 \\
\hline 6 & 1.00 & -1.00 & 1.00 & 9.00 & 16.10 & 39.90 & 0.53 & 10.4 & 11.3 & 492.6 & 43.9 \\
\hline 7 & 1.00 & 1.00 & -1.00 & 9.00 & 33.90 & 16.10 & 0.11 & 25.3 & 7.4 & 307.5 & 138.6 \\
\hline 12 & 0.00 & 1.68 & 0.00 & 7.50 & 40.00 & 25.00 & 0.35 & 28.2 & 6.9 & 195.5 & 114.1 \\
\hline 13 & 0.00 & 0.00 & -1.68 & 7.50 & 25.00 & 10.00 & 0.12 & 25.9 & 6.8 & 432.5 & 44.2 \\
\hline 14 & 0.00 & 0.00 & 1.68 & 7.50 & 25.00 & 50.00 & 1.01 & 15.3 & 10.1 & 401.0 & 242.1 \\
\hline 15 & 0.00 & 0.00 & 0.00 & 7.50 & 25.00 & 25.00 & 0.13 & 19.4 & 9.0 & 432.7 & 93.8 \\
\hline 16 & 0.00 & 0.00 & 0.00 & 7.50 & 25.00 & 25.00 & 0.21 & 18.4 & 9.4 & 460.4 & 168.5 \\
\hline 17 & 0.00 & 0.00 & 0.00 & 7.50 & 25.00 & 25.00 & 0.07 & 18.7 & 8.8 & 451.7 & 155.2 \\
\hline
\end{tabular}

${ }^{(1)} \mathrm{SDS}=$ sodium dodecyl sulfate; ${ }^{(2)} \mathrm{EOF}=$ electroosmotic flow.

where: Rs represents the resolution value; $t_{1}$ and $t_{2}$ represent the migration time of each analyzed pair compound; and $\mathrm{w}_{1}$ and $\mathrm{w}_{2}$ represent the width of each compound peak base (Collins et al., 2006).

$\mathrm{S}=\frac{\mathrm{T}_{\text {final }}-\mathrm{T}}{\mathrm{T}+\mathrm{T}_{\text {inicial }}}$

where: $\mathrm{S}=$ symmetry; $\mathrm{T}=$ time of the maximum peak height; $\mathrm{T}_{\text {final }}=$ time of the peak base end; and $\mathrm{T}_{\text {initial }}=$ time of peak base start.

Then, to simultaneously evaluate the responses and determine the best condition of analysis, the desirability function of Derringer \& Suich (1980) was used, which places a desirability value for each response, and, from that, combine them in an overall desirability (Derringer \& Suich, 1980). Data processing was conducted with Design Expert 6.0.4 (Minneapolis, USA) software.

\subsection{Method validation by capillary electrophoresis}

The method was validated in accordance with the recommendations made by the Guide for Validation of Analytical and Bioanalytical Methods (Brasil, 2017). Detection and quantification limits were estimated as being 3 and 6 times the signal - to - noise ratio, respectively. The quantification limit was based on the lowest level that presented acceptable relative coefficient variation $(\leq 20 \%)$ for the concentration evaluated. Calibration curves were constructed in random triplicates, each with 7 concentration levels, equidistantly, considering the expected concentrations in the samples. The linearity of calibration curves was evaluated and the linear model was validated by the analysis of variance (ANOVA) for lack of fit, residual distribution and significance of regression.

In order to evaluate the repeatability, 10 determinations were carried out in a single day, including 3 concentrations of calibration curves (corresponding to the quantification limit - level 1, the intermediate curve point - level 2, and the maximum concentration - level 3). Intermediate precision (between days) was evaluated through five determinations, at the same concentration levels of repeatability, in five consecutive days. For the study of accuracy through recovery, the fortification of the samples with standards in known concentrations was carried out, also following 3 curve levels (at concentrations of the quantification limit, the intermediate point and the maximum concentration) through 3 determinations at each level. Robustness was evaluated for the $\mathrm{pH}$ of the electrolyte, in an univariate way. Between the days of analysis, the method was monitored by analyzing a reference commercial sample every 4 hours.

\section{Results and discussion}

\subsection{Method optimization and experimental design}

For the direct detection system of caffeine and indirect detection of taurine, the benzoic acid was the run electrolyte chosen because it presents a chromophore in its structure, 
which has maximum absorptivity of $230 \mathrm{~nm}$, allowing indirect determination of taurine content, but that does not absorb at the $274 \mathrm{~nm}$ region, which is the wavelength of caffeine absorption.

In the univariate study of the $\mathrm{pH}$, it was observed that values above 10 increased the baseline noise substantially, and values below 5 notably extended the analysis time. As for the study of the SDS surfactant, it was proved to be effective, and it was observed that the higher the SDS concentration, the longer the analysis time.

Table 1 presents responses obtained in experiments of the central composite design $2^{3}$. Table 2 presents tests for lack of fit, significance of regression and coefficients of the models.

The taurine peak models for responses of symmetry and height showed no evidence of lack of fit. On the other hand, models of time difference between electroosmotic flow and caffeine, of resolution between taurine and caffeine, and the variation in baseline at $230 \mathrm{~nm}$ showed a slight lack of fit. Regarding the significance of the models, only the parameter of variation in baseline at $230 \mathrm{~nm}$ showed no significant regression model; however, the information is unreliable, since there was lack of fit.

When a model used for algorithms optimization presents lack of fit, the desirability function of Derringer \& Suich (1980) may not correctly estimate the optimal condition. However, it is possible to observe that the lack of fit for the responses "time difference between electroosmotic flow and caffeine", "resolution between taurine and caffeine" and "variation in baseline at $230 \mathrm{~nm}$ for taurine" was found to be small. The values of $\mathrm{F}$ calculated were 1.7, 1.2 and 3.7 times above the critical $\mathrm{F}_{\text {value }}$, respectively. Other authors have demonstrated that models with a slight lack of fit can still be useful to predict analytical conditions. Dias et al. (2015), employed models with values of $\mathrm{F}_{\text {calculated }}$ up to 10 times higher than the values of $\mathrm{F}_{\text {critical }}$, obtaining satisfactory results in the optimization of responses. Similarly, in Meinhart et al. (2011) and Ballus et al. (2014) studies, models with a slight lack of fit significantly contributed to the optimization of the analysis methods. Considering that such models presented random residual distribution, these were kept in the process of simultaneous optimization of responses.

In this study, we also conducted experimental region restrictions to reduce the error of algorithm prediction due to the model's lack of fit, as was performed in Dias et al. (2015). The experimental responses of time difference between electroosmotic flow and caffeine, indicated that the conditions of the experiments $3,5,7,10,13,15,16$ and 17 should be avoided, since the responses were unsatisfactory (difference less than $0.25 \mathrm{~min}$ ). The other response with lack of fit (baseline variation) indicates that the conditions of the tests $9,10,11$ and 14 presented a very high baseline variation (above $200 \mathrm{mUA}$ ), and such conditions should be avoided. The response for the resolution between caffeine and taurine, although presenting lack of fit, is not worrisome once all the resolutions among compounds were high. Thus, restrictions have been established to reject levels of variables that were experimentally harmful for time difference between electroosmotic flow and caffeine, and the baseline variation. As it can be seen in Table 3, the $\mathrm{pH}$ was limited to the levels from - 1.00 to 1.00 , the concentration of benzoic acid from - 1.00 to 1.68 and the SDS concentration from - 1.68 to 1.00 .

For the employment of the desirability algorithm proposed by Derringer \& Suich (1980), an individual desirability was established for each variable in order to obtain time difference between electroosmotic flow and caffeine above 0.8 and below 2.0 minutes, to obtain the smallest possible baseline variation, the highest taurine peak, and reduce the symmetry of taurine for values near 1.0 with minimum acceptable of 0.8 . For the resolution between caffeine and taurine, the desirability criterion was to reduce it (since values were too high, from 8 to 28), with the minimum limit of 3.0, resolution considered excellent for quantification. With the reduction of the values closer to 3.0, there is a tendency of reduction of the analysis time.

Table 2. Mathematical models obtained from responses of the central compound design, tests of lack of fit and significance of regressions tests.

\begin{tabular}{|c|c|c|c|c|c|c|c|c|c|c|c|c|}
\hline \multirow[b]{2}{*}{ Responses } & \multicolumn{10}{|c|}{ Coefficients of regression (errors) } & \multicolumn{2}{|c|}{$\begin{array}{c}\text { Lack of fit and Regression } \\
\text { tests }\end{array}$} \\
\hline & Intercept & $\begin{array}{c}\mathrm{A} \\
\mathrm{pH}\end{array}$ & $\begin{array}{c}\text { B } \\
\text { Benzoic } \\
\text { Acid }\end{array}$ & $\begin{array}{c}\mathrm{C} \\
\operatorname{SDS}^{(1)}\end{array}$ & $\mathrm{A}^{2}$ & $\mathrm{~B}^{2}$ & $\mathrm{C}^{2}$ & $\mathrm{AB}$ & $\mathrm{AC}$ & $\mathrm{BC}$ & $\begin{array}{c}F_{\text {Calculated }} \\
\text { Lack of fit }{ }^{(3)}\end{array}$ & $\begin{array}{c}\mathrm{F}_{\text {Calculated }} \\
\text { Regression }^{(4)}\end{array}$ \\
\hline $\begin{array}{l}\text { Time Difference } \\
\text { EOF }^{(2)} \text { and } \\
\text { Caffeine }\end{array}$ & $\begin{array}{c}0.46 \\
(0.09)\end{array}$ & $\begin{array}{l}-0.22 \\
(0.10)\end{array}$ & $\begin{array}{l}-0.06 \\
(0.10)\end{array}$ & $\begin{array}{c}0.24 \\
(0.10)\end{array}$ & - & - & - & - & - & - & 32.87 & 3.47 \\
\hline SymmetryTaurine & $\begin{array}{c}9.16 \\
(0.20)\end{array}$ & $\begin{array}{c}0.07 \\
(0.22)\end{array}$ & $\begin{array}{l}-1.52 \\
(0.22)\end{array}$ & $\begin{array}{c}0.60 \\
(0.22)\end{array}$ & - & - & - & - & - & - & 7.95 & 18.77 \\
\hline $\begin{array}{l}\text { Height of peak of } \\
\text { Taurine }\end{array}$ & $\begin{array}{l}449.88 \\
(25.02)\end{array}$ & $\begin{array}{l}-10.92 \\
(11.76)\end{array}$ & $\begin{array}{l}-83.44 \\
(11.76)\end{array}$ & $\begin{array}{c}1.33 \\
(11.76)\end{array}$ & $\begin{array}{c}28.81 \\
(12.95)\end{array}$ & $\begin{array}{l}-50.70 \\
(12.95)\end{array}$ & $\begin{array}{l}-16.62 \\
(12.95)\end{array}$ & $\begin{array}{c}-2.23 \\
(15.36)\end{array}$ & $\begin{array}{c}-8.37 \\
(15.36)\end{array}$ & $\begin{array}{c}1.15 \\
(15.36)\end{array}$ & 12.80 & 8.92 \\
\hline $\begin{array}{l}\text { Variation of } \\
\text { Baseline in }\end{array}$ & $\begin{array}{c}156.28 \\
(163.77)\end{array}$ & $\begin{array}{l}-157.68 \\
(76.95)\end{array}$ & $\begin{array}{c}10.00 \\
(76.95)\end{array}$ & $\begin{array}{c}21.75 \\
(76.95)\end{array}$ & $\begin{array}{l}171.84 \\
(84.78)\end{array}$ & $\begin{array}{l}-49.48 \\
(84.78)\end{array}$ & $\begin{array}{l}-55.91 \\
(84.78)\end{array}$ & $\begin{array}{c}21.59 \\
(100.50)\end{array}$ & $\begin{array}{c}15.56 \\
(100.50)\end{array}$ & $\begin{array}{c}14.59 \\
(100.50)\end{array}$ & 70.91 & 1.24 \\
\hline
\end{tabular}

${ }^{(1)} \mathrm{SDS}=$ sodium dodecyl sulfate; ${ }^{(2)} \mathrm{EOF}=$ electroosmotic flow; ${ }^{(3)} \mathrm{F}_{\text {critical }}$ for the test of lack of fit: 19.35 (values of $\mathrm{F}_{\text {calculated }}$ higher than $\mathrm{F}_{\text {critical }}$ indicate model with lack of fit); ${ }^{(4)} \mathrm{F}_{\text {critical }}$ for the significance of regression: 3.55 (values of $\mathrm{F}_{\text {calculated }}$ lower than $\mathrm{F}_{\text {critical }}$ indicate significative regression). 
Table 3. Conditions of desirability employed in simultaneous optimization of responses, values predicted by models and values observed.

\begin{tabular}{|c|c|c|c|c|c|c|}
\hline Variable/ Response & Criterion & Lower Limit & Upper Limit & Importance & Predicted Value & Observed Value \\
\hline $\mathrm{Ph}$ & within range & -1.00 & 1.00 & 3 & 7.26 & - \\
\hline Concentration of electrolyte & within range & -1.00 & 1.68 & 3 & 16.20 & - \\
\hline Concentration of $\operatorname{SDS}^{(1)}$ & within range & -1.68 & 1.00 & 3 & 39.90 & - \\
\hline Time Difference $\mathrm{EOF}^{(2)} /$ Caffeine & within range & 0.80 & 2.00 & 5 & 0.80 & $0.31 \pm 0.02$ \\
\hline Resolution Taurine/Caffeine & Minimize & 3.00 & 28.20 & 3 & 12.15 & $9.92 \pm 1.04$ \\
\hline Symmetry Taurine & Minimize & 0.80 & 10.00 & 5 & 11.26 & $15.55 \pm 1.47$ \\
\hline Height of peak Taurine & Maximize & 300.0 & 613.00 & 5 & 469.83 & $517.15 \pm 15.63$ \\
\hline Variation of baseline in $230 \mathrm{~nm}$ & Minimize & 1.0 & 1359.00 & 3 & 79.81 & $76.00 \pm 1.84$ \\
\hline
\end{tabular}

${ }^{(1)} \mathrm{SDS}=$ sodium dodecyl sulfate; ${ }^{(2)} \mathrm{EOF}=$ electroosmotic flow

Table 3 also presents the conditions of analysis suggested for each parameters, as well as the experimental responses provided. The analytical condition of pH 7.26, $16.20 \mathrm{mmol.L^{-1 }}$ of benzoic acid and $39.90 \mathrm{mmol}^{-1}$ of SDS were tested in triplicate, and the experimental values observed are presented in the table with their respective deviations.

Except for the response of time difference between electroosmotic flow and caffeine, other responses observed were very close to the responses provided. Differences may be attributed to the error in each one of the models due to lack of fit. However, the models were still useful for the optimization of the analytical method.

The method was validated and its parameters were: linear range from 4 to $84 \mathrm{mg} . \mathrm{L}^{-1}$ for caffeine and from 15 to $235 \mathrm{mg} . \mathrm{L}^{-1}$ for taurine; lack of fit of 6.76 for caffeine and 2.59 for taurine; detection limit of $2 \mathrm{mg} . \mathrm{L}^{-1}$ for caffeine and $7.5 \mathrm{mg} . \mathrm{L}^{-1}$ for taurine; quantification limit of $4 \mathrm{mg} . \mathrm{L}^{-1}$ for caffeine and $15 \mathrm{mg} \cdot \mathrm{L}^{-1}$ for taurine; repeatability $(\mathrm{n}=10)$ with coefficient of variation of $15.93 \%$ (level 1), 8.21\% (level 2) and 8.75\% (level 3) for caffeine, and for taurine the values were $13.80 \%$ (level 1), 13.25\% (level 2) and $9.08 \%$ (level 3 ); intermediate precision $(n=5)$ with coefficient of variation of $10.57 \%$ (level 1), 5.59\% (level 2) and 3.97\% (level 3) for caffeine, and for taurine the values were $14.27 \%$ (level 1), $13.12 \%$ (level 2) and $10.57 \%$ (level 3). Recovery $(n=3)$ values were $105.11 \%$ (level 1), 111.26\% (level 2) and 118.83\% (level 3) for caffeine, and for taurine the values were $117.18 \%$ (level 1), $120.81 \%$ (level 2) and $115.40 \%$ (level 3). The concentrations for the repeatability, intermediate precision and recovery at levels 1, 2 and 3, were equivalent to 4,40 and 84 mg. $\mathrm{L}^{-1}$ for caffeine and 15, 110 and 235 mg. $\mathrm{L}^{-1}$ for taurine, respectively. Regarding the robustness of the $\mathrm{pH}$ of the run electrolyte, it was observed that there was no significant difference in retention times and areas (in standard and control sample) when the electrolyte was prepared with $\mathrm{pH}$ variation from 7.21 to 7.29.

Through the analysis of variance, the linear regression was significant in the concentration ranges studied and the mathematical model for the caffeine presented a slight lack of fit(due to the low experimental error) and the mathematical model for taurine showed no lack of fit $(p>0.05)$, proving to be appropriate to perform quantifications. Quantification limits were suitable for energy drinks analysis with an extremely simple extraction method. The other parameters also presented suitable results for the quantification according to the requirements of ANVISA (Brasil, 2003), demonstrating that the method is reliable for the simultaneous determination of caffeine and taurine contents in energy drinks.

In the literature, the caffeine content is generally determined by HPLC, using mobile phases containing water and methanol or acetonitrile (Rahim et al., 2014)or by capillary electrophoresis (Vochyánová et al., 2014), both with DAD detection. They are simple analysis methods and have a short running time (less than 10 minutes). Taurine content analysis, usually performed by HPLC, requires indirect detectors (Cao et al., 2003) or must be preceded by derivatization reactions (Mou et al., 2002; Zinellu et al., 2009) for detection by DAD or fluorescence. Derivatization reactions are expensive and may be incomplete (Mou et al., 2002). The method developed and validated in the present study has the advantage of quantifying both compounds in a single analysis, using only one detector, without the use of organic solvents, with a short time of analysis and an extremely simple sample preparation.

\subsection{Determination of caffeine and taurine contents in energy drinks sample}

Figure 1 presents an electropherogram obtained in the determination of caffeine and taurine contents in a sample of energy drink, and Table 4 presents the average concentrations of caffeine and taurine in each batch of 22 energy drink brands analyzed.

Regarding the caffeine content present in 22 analyzed brands, it ranged from $19.8 \mathrm{mg} .100 \mathrm{~mL}^{-1}$ to $31.5 \mathrm{mg} .100 \mathrm{~mL}^{-1}$, and brand 16 presented the lowest level, which was also significantly different $(\mathrm{p}<0.05)$ from the content found in brands $12 c, 13,19,20,21$. These, in turn, were not statistically different from each other.

As for the taurine content, it was observed that the value ranged from $313.0 \mathrm{mg} .100 \mathrm{~mL}^{-1}$ to $489.4 \mathrm{mg} .100 \mathrm{~mL}^{-1}$. All brands were statistically equal to each other $(\mathrm{p}<0.05)$, except for brand 1 in relation to brand 16 .

When the difference of the caffeine and taurine levels between batches of the same brand was investigated, it was verified that for caffeine, only 6 brands presented statistical equality between the batches and that 16 brands had at least one batch different from 

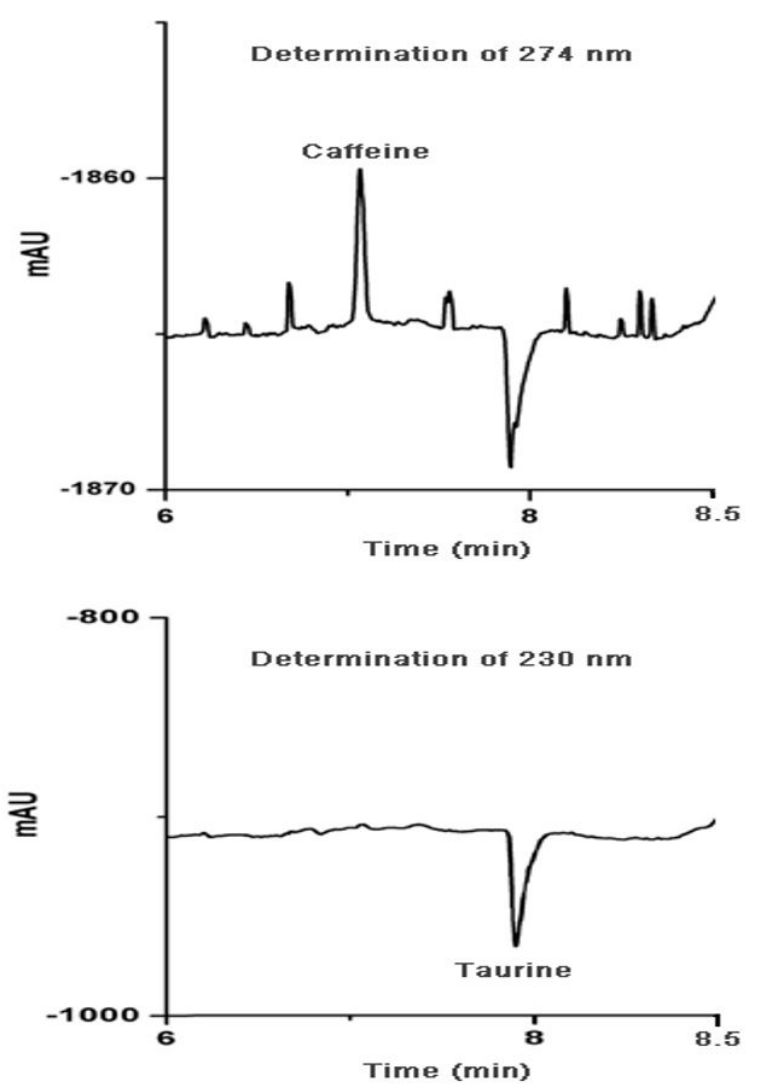

Figure 1. Electropherogram obtained in the determination of caffeine and taurine in a sample of energy drink. Capillary of $50 \mu \mathrm{m}$ of i.d. $\mathrm{x} 72 \mathrm{~cm}$ of effective length with extended bulb, electrolyte benzoic

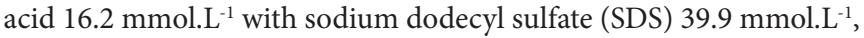
$\mathrm{pH} 7.26,30 \mathrm{kV}, 25^{\circ} \mathrm{C}$, injection of 50 mbar for $5 \mathrm{~s}$ and detection at $274 \mathrm{~nm}$ (caffeine) and at $230 \mathrm{~nm}$ (taurine). the others. For taurine content, 9 brands presented statistical equality between the batches and 13 had different taurine content in at least one of the batches.

In Accordance with ANVISA, the value declared on the label of energy drinks should be equivalent to the content present in the drink, without any tolerance (Brasil, 2005). Comparing the caffeine content with the value declared on the label and with values of confidence intervals, it was found that among the 22 brands analyzed, 21 presented at least one batch with caffeine content below the declared value, and from these, 9 brands had all batches with levels below the ones declared. Only the brand 20 presented all batches with the same concentrations of caffeine declared on the label.

Regarding taurine content, 11 brands presented at least one batch with value below the one declared on the label. Only 4 brands presented all batches with the same taurine concentrations as the ones declared on the label.

According to ANVISA (Brasil, 2005), the caffeine and taurine content present in samples must be below the legal limit, without tolerance, being $35 \mathrm{mg} .100 \mathrm{~mL}^{-1}$ and $400 \mathrm{mg} .100 \mathrm{~mL}^{-1}$, respectively. From the confidence intervals ( $95 \%$ ), it was possible to observe that no brand presented the caffeine content above the maximum limit allowed. Regarding taurine content, $50 \%$ of the brands presented at least a batch above the maximum limit allowed. Similar results were found for caffeine by McCusker et al. (2006) using gas chromatography with nitrogen-phosphorus detector, and by Ballus et al. (2012) using the technique of micellar electrokinetic chromatography with DAD (MEKC) detection system.

Table 4. Average content of caffeine and taurine and the confidence interval (95\%) of analysed energy drinks samples.

\begin{tabular}{|c|c|c|c|c|c|c|c|}
\hline \multirow[b]{2}{*}{ Brands } & \multirow[b]{2}{*}{ Batch } & \multicolumn{3}{|c|}{ Caffeine } & \multicolumn{3}{|c|}{ Taurine } \\
\hline & & $\begin{array}{l}\text { Concentration } \\
\left(\mathrm{mg} .100 \mathrm{~mL}^{-1}\right)\end{array}$ & CI (95\%) & DV & $\begin{array}{l}\text { Concentration } \\
\left(\mathrm{mg} .100 \mathrm{~mL}^{-1}\right)\end{array}$ & CI (95\%) & DV \\
\hline \multirow[t]{4}{*}{1} & $\mathrm{~A}$ & $24.9 \pm 1.2^{\mathrm{a}}$ & $21.9-27.9$ & 32.0 & $614.2 \pm 5.7^{\mathrm{a}}$ & $525.4-703.0$ & 400.0 \\
\hline & B & $25.9 \pm 1.9^{\mathrm{a}}$ & $21.0-30.8$ & & $397.0 \pm 9.9^{b}$ & $372.5-421.5$ & \\
\hline & $\mathrm{C}$ & $25.3 \pm 1.4^{\mathrm{a}}$ & $21.9-28.6$ & & $457.1 \pm 13.1^{\mathrm{b}}$ & $400.4-513.8$ & \\
\hline & Average & $25.4 \pm 0.5$ & & & $489.4 \pm 112.2$ & & \\
\hline \multirow[t]{4}{*}{2} & A & $25.1 \pm 0.8^{\mathrm{a}}$ & $23.1-27.0$ & 31.9 & $353.9 \pm 10.4^{\mathrm{a}}$ & $256.1-451.8$ & 400.0 \\
\hline & B & $25.6 \pm 1.6^{\mathrm{a}}$ & $21.8-29.5$ & & $407.6 \pm 7.3^{\mathrm{a}}$ & $389.4-425.7$ & \\
\hline & $\mathrm{C}$ & $26.1 \pm 1.5^{\mathrm{a}}$ & $22.3-30.0$ & & $412.1 \pm 14.5^{\mathrm{a}}$ & $376.1-448.0$ & \\
\hline & Average & $25.6 \pm 0.5$ & & & $391.2 \pm 32.3$ & & \\
\hline \multirow[t]{4}{*}{3} & A & $27.6 \pm 1.4^{\mathrm{a}}$ & $24.1-31.0$ & 32.0 & $361.0 \pm 10.8^{c}$ & $334.1-387.9$ & 400.0 \\
\hline & B & $21.4 \pm 1.6^{\mathrm{b}}$ & $17.4-25.4$ & & $434.5 \pm 4.3^{\mathrm{b}}$ & $423.8-445.1$ & \\
\hline & $\mathrm{C}$ & $28.1 \pm 0.2^{\mathrm{a}}$ & $27.7-28.5$ & & $459.4 \pm 6.8^{\mathrm{a}}$ & $442.7-476.2$ & \\
\hline & Average & $25.7 \pm 3.7$ & & & $418.3 \pm 51.1$ & & \\
\hline \multirow[t]{4}{*}{$4^{(1)}$} & A & $25.0 \pm 1.2^{\mathrm{a}}$ & $22.1-27.8$ & 29.7 & $405.0 \pm 26.7^{\mathrm{a}}$ & $338.7-471.3$ & 371.7 \\
\hline & B & $27.1 \pm 2.4^{\mathrm{a}}$ & $21.1-33.0$ & & $447.7 \pm 10.9^{\mathrm{a}}$ & $420.5-474.9$ & \\
\hline & $\mathrm{C}$ & $23.5 \pm 0.2^{\mathrm{a}}$ & $23.1-23.9$ & & $454.8 \pm 29.8^{\mathrm{a}}$ & $380.5-528.7$ & \\
\hline & Average & $25.2 \pm 1.8$ & & & $435.8 \pm 26.9$ & & \\
\hline
\end{tabular}

${ }^{(1)}$ traditional flavor; ${ }^{(2)}$ zero sugar; ${ }^{(3)}$ flavored. CI $(95 \%)=$ confidence interval of $95 \%\left(\mathrm{n}=3, \mathrm{t}_{2}=4.303\right)$; DV = Declared value on the label $\left(\mathrm{mg} .100 \mathrm{~mL}{ }^{-1}\right)$. Identical lower case letters between batches of the same brand indicate that there is no significant difference between batches according to the Tukey test ( $95 \%$ of confidence). 
Table 4. Continued...

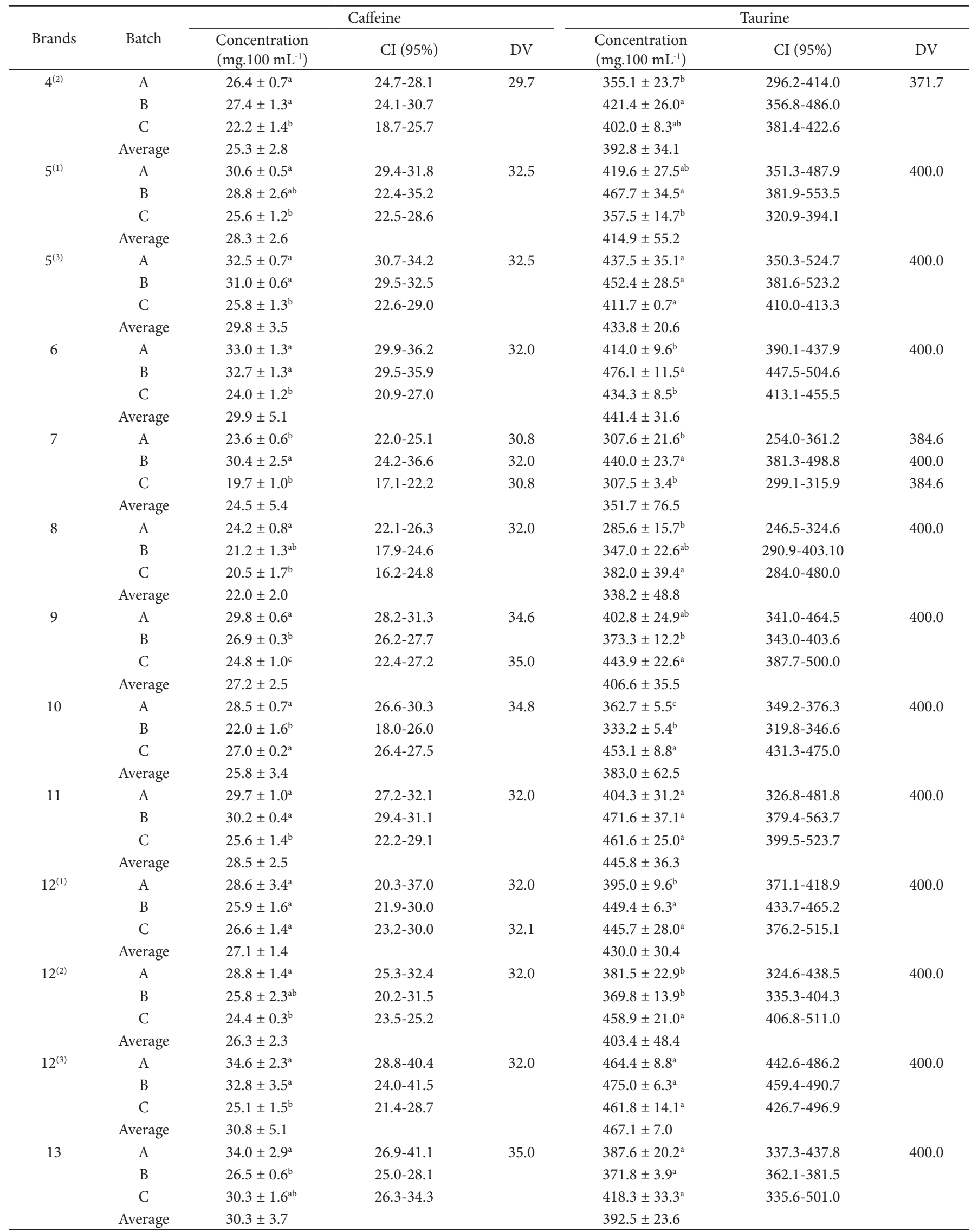

${ }^{(1)}$ traditional flavor; ${ }^{(2)}$ zero sugar; ${ }^{(3)}$ flavored. CI $(95 \%)=$ confidence interval of 95\% $\left(\mathrm{n}=3, \mathrm{t}_{2}=4.303\right)$; DV = Declared value on the label (mg.100 $\left.\mathrm{mL} \mathrm{L}^{-1}\right)$. Identical lower case letters between batches of the same brand indicate that there is no significant difference between batches according to the Tukey test (95\% of confidence). 
Table 4. Continued...

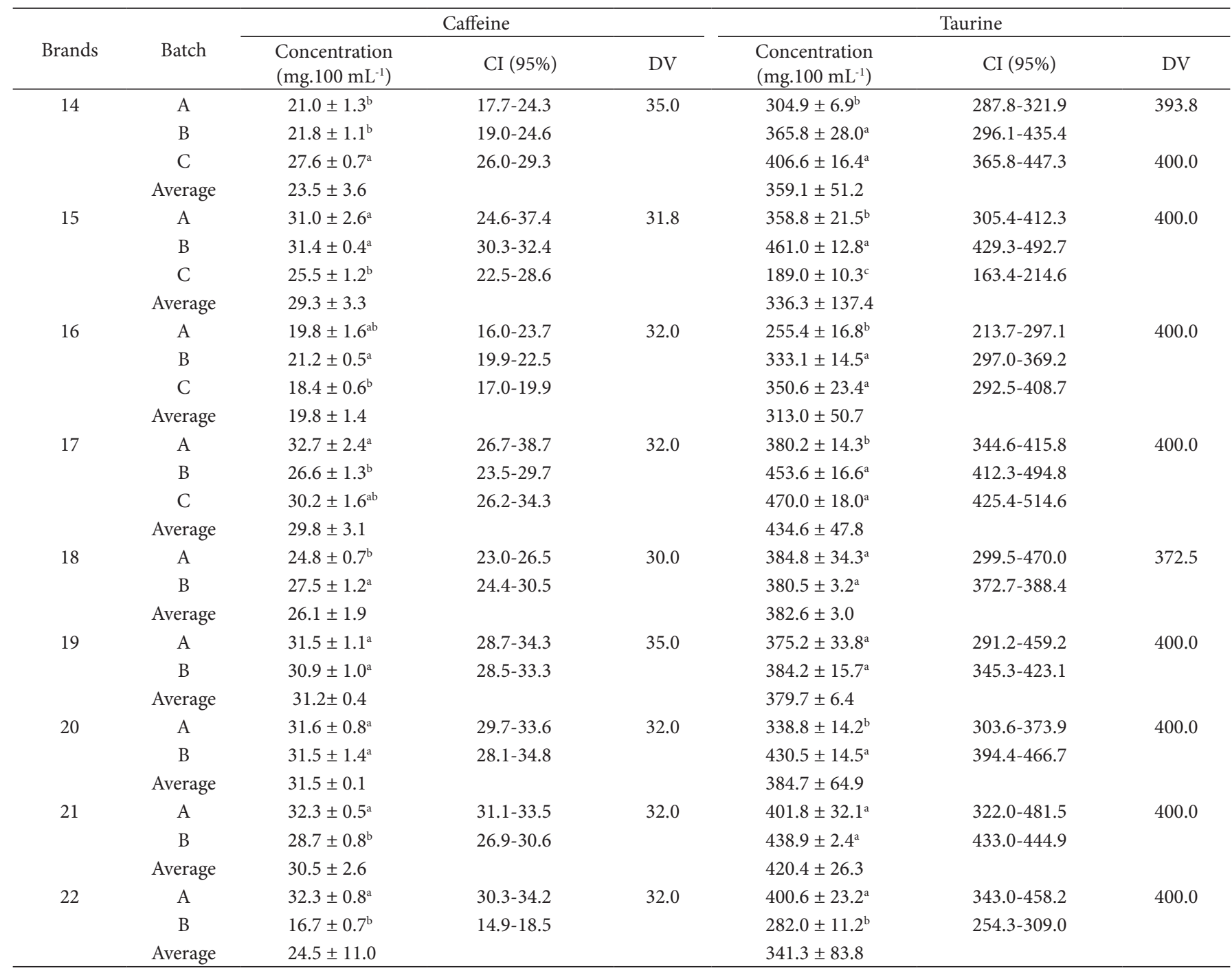

${ }^{(1)}$ traditional flavor; ${ }^{(2)}$ zero sugar; ${ }^{(3)}$ flavored. CI $(95 \%)=$ confidence interval of $95 \%\left(\mathrm{n}=3, \mathrm{t}_{2}=4.303\right)$; DV $=$ Declared value on the label $\left(\mathrm{mg} .100 \mathrm{~mL}{ }^{-1}\right)$. Identical lower case letters between batches of the same brand indicate that there is no significant difference between batches according to the Tukey test (95\% of confidence).

\section{Conclusion}

The developed method showed appropriate validation parameters for the determination of the compounds in energetic samples, showing its applicability in the detection of caffeine and taurine contents by $\mathrm{CE}$ with low reagent costs, reduced analysis time, minimum residue generation, no exposure of the analyst to toxic solvents, and extremely simple sample preparation.

As for the evaluation of different samples of energy drinks, the caffeine content was always below the maximum limit allowed; on the other hand, the taurine content in $50 \%$ of the samples was above the maximum limit allowed in Brazilian legislation for energy drinks. From 73 samples, 68\% showed an amount of caffeine statistically lower than the one declared on the product label, whereas for taurine, only $19 \%$ showed an amount lower than the one declared on the product label, being in disagreement with Brazilian legislation.

Most brands presented heterogeneity in the caffeine and taurine contents among analyzed batches from the same brand.
These differences between batches of the same brand show the need for a stricter control on standardization of added ingredients.

\section{References}

Alzawqari, M., Al-Baadani, H. H., Alhidary, I. B., Al-Owaimer, A., \& Abudabos, A. (2016). Effect of taurine and bile acid supplementation and their interaction on performance, serum components, ileal viscosity and carcass characteristics of broiler chickens. South African Journal of Animal Science, 46(4), 448. http://dx.doi.org/10.4314/ sajas.v46i4.13.

Ballus, C. A., Meinhart, A. D., Bizzotto, C. S., Teixeira, J. Fo., \& Godoy, H. T. (2012). A fast and efficient method for the study of caffeine levels in energy drinks using micellar electrokinetic chromatography (MEKC). Food Science and Technology, 32(2), 401-404. http://dx.doi. org/10.1590/S0101-20612012005000042.

Ballus, C. A., Meinhart, A. D., de Souza Campos, F. A. Jr., Bruns, R. E., \& Godoy, H. T. (2014). Doehlert design-desirability function multicriteria optimal separation of 17 phenolic compounds from extravirgin olive oil by capillary zone electrophoresis. Food Chemistry, 
146, 558-568. http://dx.doi.org/10.1016/j.foodchem.2013.09.102. PMid:24176381.

Bizzotto, C. S., Meinhart, A. D., Ballus, C. A., Ghiselli, G., \& Godoy, H. T. (2013). Comparison of capillary electrophoresis and high performance liquid chromatography methods for caffeine determination in decaffeinated coffee. Food Science and Technology, 33(1), 186-191. http://dx.doi.org/10.1590/S0101-20612013005000013.

Brasil, Agência Nacional de Vigilância Sanitária - ANVISA. (2003, June 2). Guia para validação de métodos analíticos e bioanalíticos (Resolução RE no 899, de 29 de maio de 2003). Diário Oficial [da] República Federativa do Brasil.

Brasil, Agência Nacional de Vigilância Sanitária - ANVISA. (2005, September 23). Aprova o regulamento técnico para misturas para o preparo de alimentos e alimentos prontos para o consumo (Resolução RDC n 273, de 22 de setembro de 2005). Diário Oficial [da] República Federativa do Brasil.

Brasil, Agência Nacional de Vigilância Sanitária - ANVISA. (2017, July 25). Dispõe sobre a validação de métodos analíticose dá outras providências (Resolução RDC nº 166, de 24 de julho de 2017). Diário Oficial [da] República Federativa do Brasil.

Cao, Y., Zhang, X., Chu, Q., Fang, Y., \& Ye, J. (2003). Determination of taurine in Lycium Barbarum L. and other foods by capillary electrophoresis with electrochemical detection. Electroanalysis, 15(10), 898-902. http://dx.doi.org/10.1002/elan.200390112.

Catharino, R. R., Haddad, R., Godoy, H. T., Eberlin, M. N., \& Santos, L. S. (2011). Fast analysis of taurine in energetic drinks by electrospray ionization mass spectrometry. Journal of the Brazilian Chemical Society, 22(4), 801-806. http://dx.doi.org/10.1590/S0103-50532011000400026.

Chirita Tampu, R. I., Finaru, A., \& Elfakir, C. (2018). Optimization of a HPLC analysis method for taurine and caffeine in energy drinks. Scientific Study \& Research: Chemistry \& Chemical Engineering, Biotechnology, Food Industry, 19(1), 23-32.

Collins, C. H., Braga, G. L., \& Bonato, P. S. (2006). Fundamentos de cromatografia. Campinas: UNICAMP.

Derringer, G., \& Suich, R. (1980). Simultaneous optimization of several response variables. Journal of Quality Technology, 12(4), 214-219. http://dx.doi.org/10.1080/00224065.1980.11980968.

Dias, C. B., Meinhart, A. D., Pane, D. Q., Ballus, C. A., \& Godoy, H. T. (2015). multivariate optimisation and validation of a method for the separation of five artificial sweeteners by UPLC-DAD in nine food matrices. Food Analytical Methods, 8(7), 1824-1835. http:// dx.doi.org/10.1007/s12161-014-0056-8.

Giles, G. E., Mahoney, C. R., Brunyé, T. T., Gardony, A. L., Taylor, H. A., \& Kanarek, R. B. (2012). Differential cognitive effects of energy drink ingredients: caffeine, taurine, and glucose. Pharmacology, Biochemistry, and Behavior, 102(4), 569-577. http://dx.doi.org/10.1016/j. pbb.2012.07.004. PMid:22819803.

Goron, A., \& Moinard, C. (2018). Amino acids and sport: a true love story? Amino Acids, 50(8), 969-980. http://dx.doi.org/10.1007/ s00726-018-2591-x. PMid:29855718.

Heckman, M. A., Sherry, K., \& Mejia, E. G. D. (2010). Energy drinks: an assessment of their market size, consumer demographics, ingredient profile, functionality, and regulations in the United States. Comprehensive Reviews in Food Science and Food Safety, 9(3), 303-317. http://dx.doi.org/10.1111/j.1541-4337.2010.00111.x.

Heidari, R., Jamshidzadeh, A., Niknahad, H., Mardani, E., Ommati, M. M., Azarpira, N., Khodaei, F., Zarei, A., Ayarzadeh, M., Mousavi, S., Abdoli, N., Yeganeh, B. S., Saeedi, A., \& Najibi, A. (2016). Effect of taurine on chronic and acute liver injury: focus on blood and brain ammonia. Toxicology Reports, 3, 870-879. http://dx.doi.org/10.1016/j. toxrep.2016.04.002. PMid:28959615.

Jakopin, Ž. (2019). Risks associated with fat burners: a toxicological perspective. Food and Chemical Toxicology, 123, 205-224. http:// dx.doi.org/10.1016/j.fct.2018.10.051. PMid:30401639.

McCusker, R. R., Goldberger, B. A., \& Cone, E. J. (2006). Caffeine content of energy drinks, carbonated sodas, and other beverages. Journal of Analytical Toxicology, 30(2), 112-114. http://dx.doi.org/10.1093/ jat/30.2.112. PMid:16620542.

McLellan, T. M., Caldwell, J. A., \& Lieberman, H. R. (2016). A review of caffeine's effects on cognitive, physical and occupational performance. Neuroscience and Biobehavioral Reviews, 71, 294-312. http://dx.doi. org/10.1016/j.neubiorev.2016.09.001. PMid:27612937.

Meinhart, A. D., Ballus, C. A., Bruns, R. E., Pallone, J. A. L., \& Godoy, H. T. (2011). Chemometrics optimization of carbohydrate separations in six food matrices by micellar electrokinetic chromatography with anionic surfactant. Talanta, 85(1), 237-244. http://dx.doi. org/10.1016/j.talanta.2011.03.056. PMid:21645694.

Mele, A., Mantuano, P., De Bellis, M., Rana, F., Sanarica, F., Conte, E., Morgese, M. G., Bove, M., Rolland, J. F., Capogrosso, R. F., Pierno, S., Camerino, G. M., Trabace, L., \& De Luca, A. (2019). A long-term treatment with taurine prevents cardiac dysfunction in $\mathrm{mdx}$ mice. Translational Research, 204, 82-99. http://dx.doi.org/10.1016/j. trsl.2018.09.004. PMid:30347179.

Mou, S., Ding, X., \& Liu, Y. (2002). Separation methods for taurine analysis in biological samples. Journal of Chromatography. B, Analytical Technologies in the Biomedical and Life Sciences, 781(1-2), 251-267. http://dx.doi.org/10.1016/S1570-0232(02)00619-0. PMid:12450662.

Pansani, M. C., Azevedo, P. S., Rafacho, B. P. M., Minicucci, M. F., Chiuso-Minicucci, F., Zorzella-Pezavento, S. G., Marchini, J. S., Padovan, G. J., Fernandes, A. A., Matsubara, B. B., Matsubara, L. S., Zornoff, L. A., \& Paiva, S. A. (2012). Atrophic cardiac remodeling induced by taurine deficiency in wistar rats. PLoS One, 7(7), e41439. http://dx.doi.org/10.1371/journal.pone.0041439. PMid:22844478.

Paula Lima, J., \& Farah, A. (2019). Methylxanthines in stimulant foods and beverages commonly consumed in Brazil. Journal of Food Composition and Analysis, 78, 75-85. http://dx.doi.org/10.1016/j. jfca.2019.02.001.

Pereira, J. C., Silva, R. G., Fernandes, A. A., \& Marins, J. C. B. (2012). Efeito da ingestão de taurina no desempenho físico: uma revisão sistemática. Revista Andaluza de Medicina del Deporte, 5(4), 156162. http://dx.doi.org/10.1016/S1888-7546(12)70024-2.

Rahim, A. A., Nofrizal, S., \& Saad, B. (2014). Rapid tea catechins and caffeine determination by HPLC using microwave-assisted extraction and silica monolithic column. Food Chemistry, 147, 262-268. http:// dx.doi.org/10.1016/j.foodchem.2013.09.131. PMid:24206716.

Rai, K. P., Rai, H. B., Dahal, S., Chaudhary, S., \& Shrestha, S. (2016). Determination of caffeine and taurine contents in energy drinks by HPLC-UV. Journal of Food Science and Technology Nepal, 9, 66-73. http://dx.doi.org/10.3126/jfstn.v9i0.16199.

Reid, J. L., McCrory, C., White, C. M., Martineau, C., Vanderkooy, P., Fenton, N., \& Hammond, D. (2016). Consumption of caffeinated energy drinks among youth and young adults in Canada. Preventive Medicine Reports, 5, 65-70. http://dx.doi.org/10.1016/j.pmedr.2016.11.012. PMid:27920973.

Sanctis, V., Soliman, N., Soliman, A. T., Elsedfy, H., Di Maio, S., El Kholy, M., \& Fiscina, B. (2017). Caffeinated energy drink consumption among adolescents and potential health consequences associated with their use: a significant public health hazard. Acta Biomedica, 88(2), 222231. http://dx.doi.org/10.23750/abm.v88i2.6664. PMid:28845841. 
Sawabe, Y., Tagami, T., \& Yamasaki, K. (2008). Determination of taurine in energy drinks by HPLC using a pre-column derivative. Journal of Health Science, 54(6), 661-664. http://dx.doi.org/10.1248/jhs.54.661.

Seifert, S. M., Schaechter, J. L., Hershorin, E. R., \& Lipshultz, S. E. (2011). Health effects of energy drinks on children, adolescents, and young adults. Pediatrics, 127(3), 511-528. http://dx.doi.org/10.1542/ peds.2009-3592. PMid:21321035.

Temple, J. L. (2019). Review: trends, safety, and recommendations for caffeine use in children and adolescents. Journal of the American Academy of Child and Adolescent Psychiatry, 58(1), 36-45. http:// dx.doi.org/10.1016/j.jaac.2018.06.030. PMid:30577937.

Tran, N. L., Barraj, L. M., Bi, X., \& Jack, M. M. (2016). Trends and patterns of caffeine consumption among US teenagers and young adults, NHANES 2003-2012. Food and Chemical Toxicology, 94, 227-242. http://dx.doi.org/10.1016/j.fct.2016.06.007. PMid:27288929.

Turak, F., Güzel, R., \& Dinç, E. (2017). Simultaneous determination of ascorbic acid and caffeine in commercial soft drinks using reversedphase ultraperformance liquid chromatography. Journal of Food and Drug Analysis, 25(2), 285-292. http://dx.doi.org/10.1016/j. jfda.2016.09.004. PMid:28911669.
Vochyánová, B., Opekar, F., \& Tưma, P. (2014). Simultaneous and rapid determination of caffeine and taurine in energy drinks by MEKC in a short capillary with dual contactless conductivity/ photometry detection. Electrophoresis, 35(11), 1660-1665. http:// dx.doi.org/10.1002/elps.201300480. PMid:24285507.

Welch, C. J., Regalado, E. L., Kraml, C., Welch, E. C., Welch, M. J., Semmelhack, H., Almstead, D., Kress, A. S., Hidalgo, N. A., \& Kress, M. H. (2015). MISER LC-MS analysis of teas, soft drinks and energy drinks. LCGC North America, 33(4), 262-269.

Wen, C., Li, F., Zhang, L., Duan, Y., Guo, Q., Wang, W., He, S., Li, J., \& Yin, Y. (2019). Taurine is involved in energy metabolism in muscles, adipose tissue, and the liver. Molecular Nutrition \& Food Research, 63(2), e1800536. http://dx.doi.org/10.1002/mnfr.201800536. PMid:30251429.

Zinellu, A., Sotgia, S., Scanu, B., Chessa, R., Gaspa, L., Franconi, F., Deiana, L., \& Carru, C. (2009). Taurine determination by capillary electrophoresis with laser-induced fluorescence detection: from clinical field to quality food applications. Amino Acids, 36(1), 35-41. http://dx.doi.org/10.1007/s00726007-0022-5. PMid:18193477. 